\title{
$I 19,3$ \\ A Preliminary Report on the Precambrian Iron Deposits Near Atlantic City, Wyoming
}

G LOGICAL SURVEY BULLETIN 1142 - C

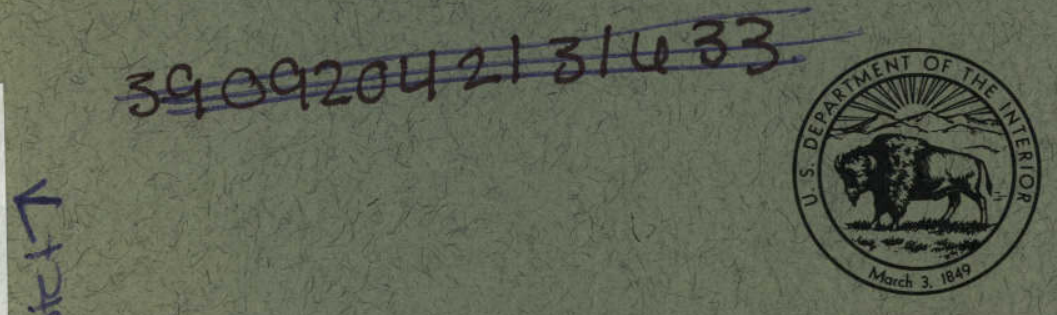




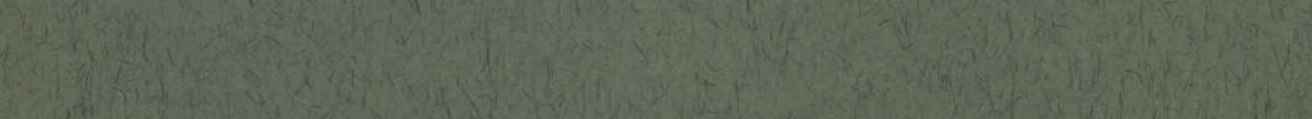

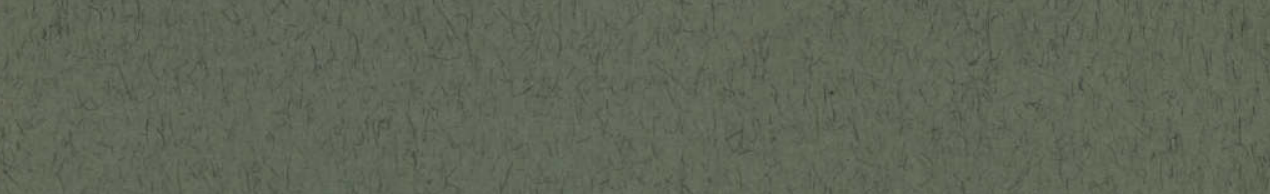
106.

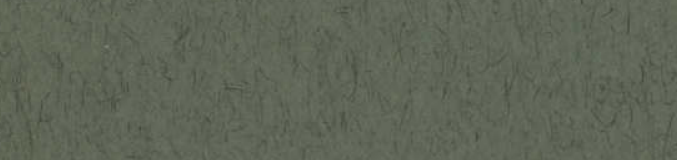

and 1.

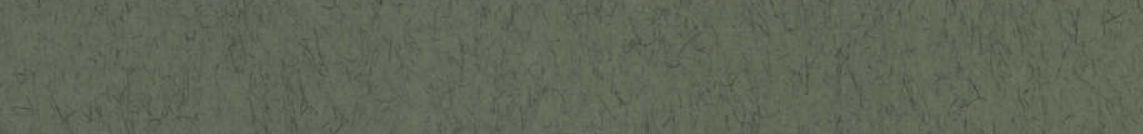

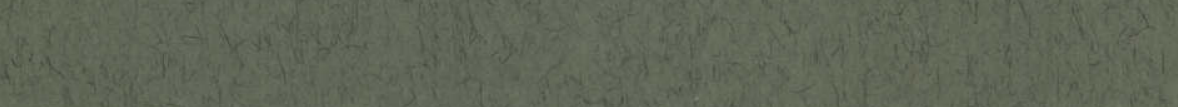

38.

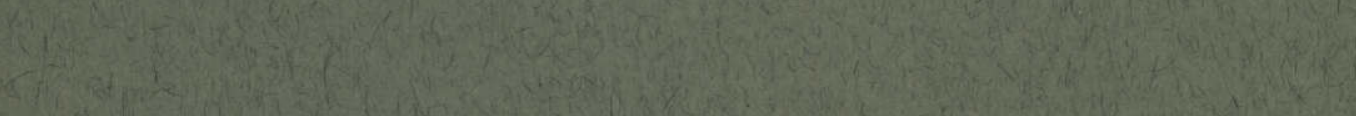
act 2)

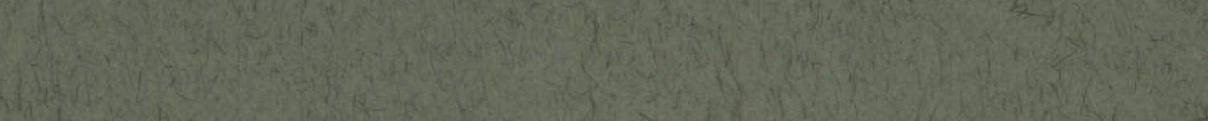

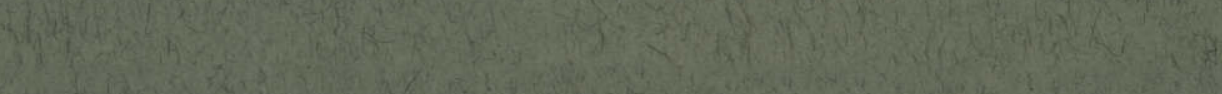

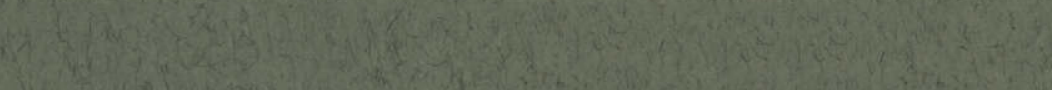
M. Now

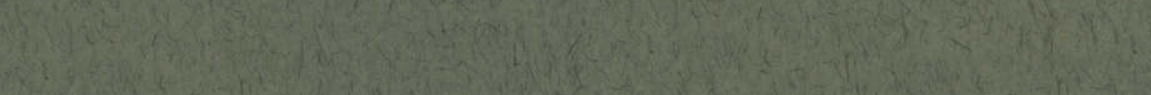

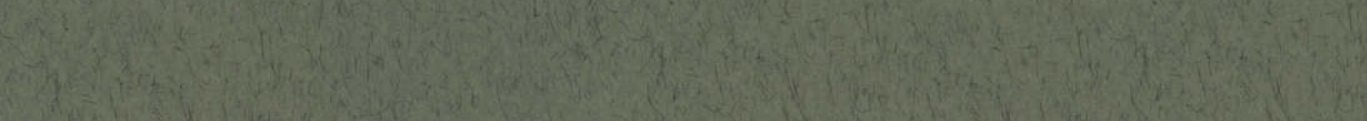

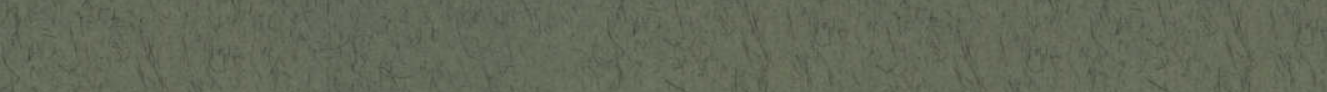

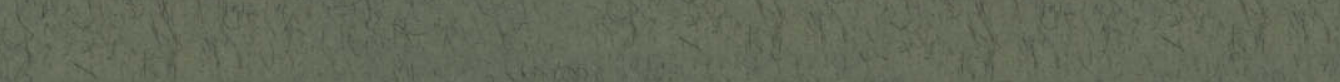

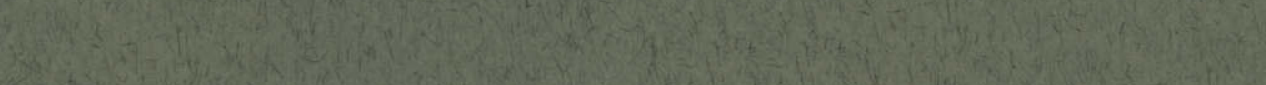

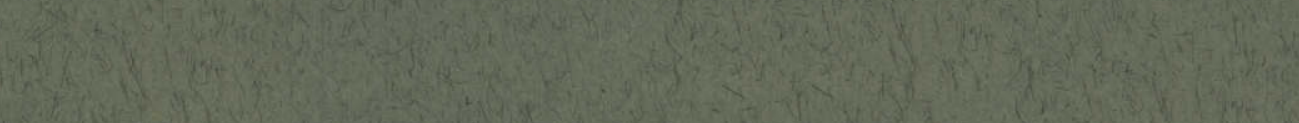

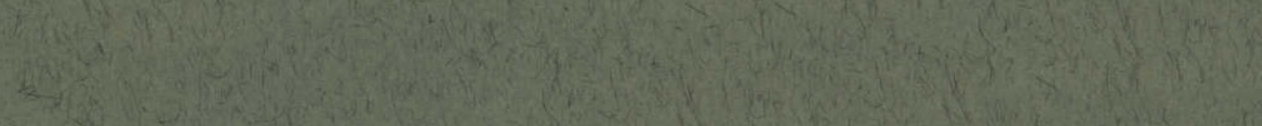

(5)

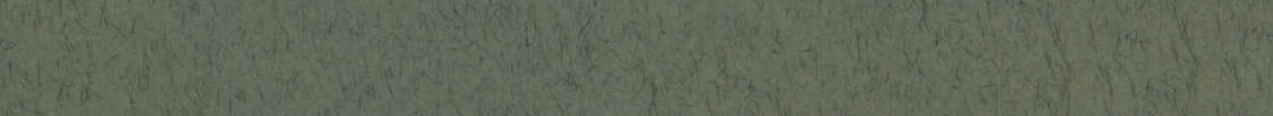

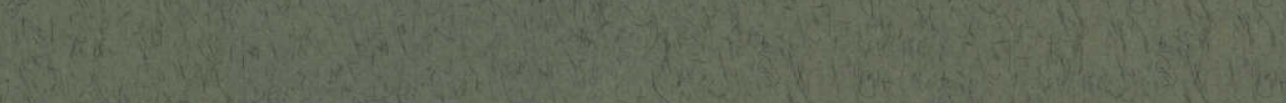
(1)

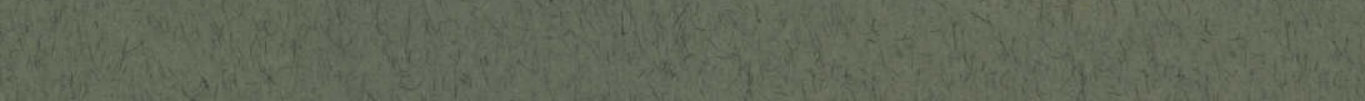

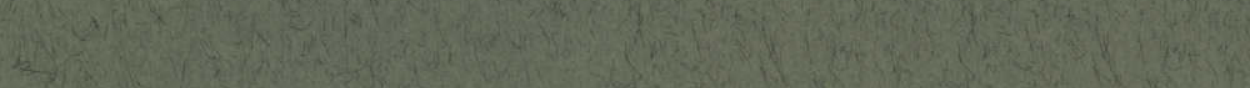


A Preliminary Report on the Precambrian Iron

Deposits Near Atlantic City, Wyoming

By RICHARD W. BAYLEY

CONTRIBUTIONS TO ECONOMIC GEOLOGY

G E O L O I C A L S U R V E Y B U L L E T I N $11+2-\mathrm{C}$
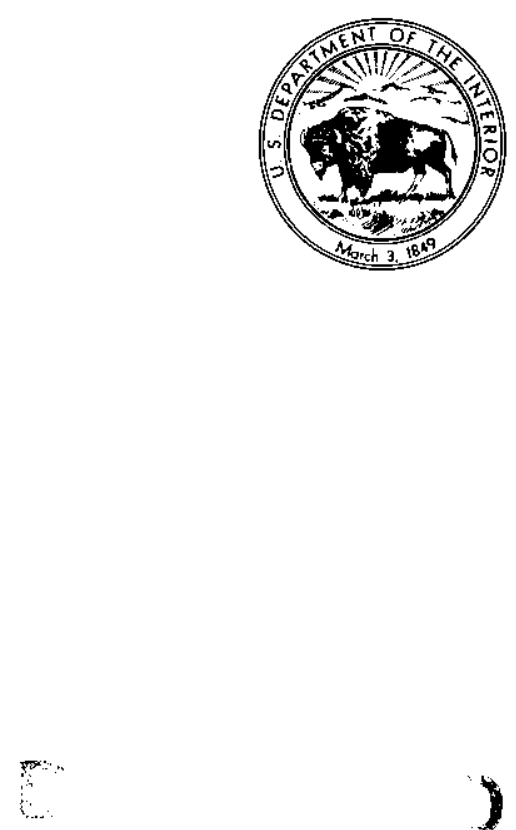


\section{UNITED STATES DEPARTMENT OF THE INTERIOR}

STEWART L. UDALL, Secretary

GEOLOGICAL SURVEY

Thomas B. Nolan, Director 


\section{CONTENTS}

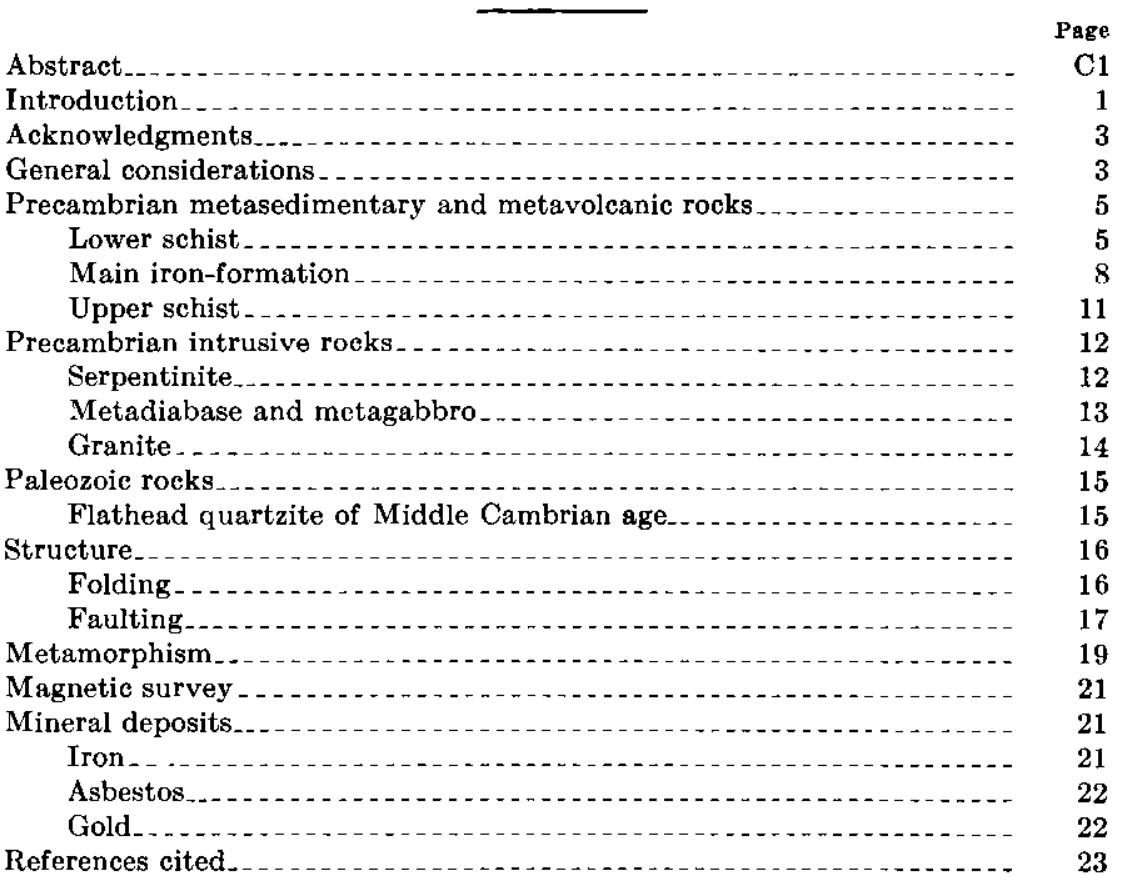

\section{ILLUSTRATIONS}

[Plates are in pocket]

Plate 1. Geologic map and section of iron deposits near Atlantic City, Fremont County, Wyo.

2. Magnetic map of the iron deposits near Atlantic City.

Figure 1. Map showing location and geologic setting

2. Photographs of iron-formation specimens. 



\title{
CONTRIBUTIONS TO ECONOMIC GEOLOGY
}

\section{A PRELIMINARY REPORT ON THE PRECAMBRIAN IRON DEPOSITS NEAR ATLANTIC CITY, WYOMING}

\author{
By RichaRd W. BaYLEY
}

\begin{abstract}
The Atlantic district, in the south part of the Wind River Range, Fremont County, Wyo., includes 100 square miles of metamorphosed Precambrian sedimentary and voleanic rocks. It is best known as a gold-mining district, but iron deposits of much greater economic potential are being developed in the northwest part.

The iron-formation is a sedimentary quartz-magnetite taconite about 100 feet thick which forms the middle part of a continuous sequence of bedded rocks. It is underlain by quartzose schist and metavolcanic rocks, and the whole sequence is disposed in the limbs of steeply pitching synclines.

The Precambrian rocks are cut by many oblique reverse faults and by a few transverse normal faults. Sheared metadiabase and metagabbro dikes mark the location of most of the oblique faults.

Intrusive rocks of three types cut the metamorphosed Precambrian rocks: (a) a sill-like body of serpentinite (metaperidotite), the oldest, (b) dikes of metadiabase and metagabbro, and $(c)$ batholithic granite, the youngest.

The metamorphism of the rocks is district wide and regional in character except very close to the granite contact where the metamorphic grade increases abruptly. Amphibolite facies rocks are most common, and most of these show the effects of retrograde metainorphism.

The magnetite content of the iron-formation is 40 to 50 percent; the grain size is small, but the naterial is suitable for magnetic separation after fine grinding. The total reserves are large.
\end{abstract}

\section{INTRODUCTION}

The iron-bearing rocks described herein are folded and faulted stratified metasedimentary rocks of Precambrian age. They occupy a narrow, northeastward-trending belt in the extreme north part of the Atlantic district, Fremont County, Wyo. (Spencer, 1916, p. 17-18, and pl. 1). 
The iron deposits were first mapped geologically by Arthur C. Spencer (1916) who, although he spent only 1 day in the area, nevertheless mapped the general distribution of the deposits and collected samples for chemical analyses.

Spencer observed that these fine-grained dense and hard rocks, (taconite by current terminology) which by his analyses contain 37 to 43 percent iron and 40 to 47 percent insoluble siliceous matter, could not be profitably smelted, and that they could be utilized only by submitting them to some process of concentration. He stated that, "crushing would be expensive, as extremely fine crushing would be necessary in order to free the grains of magnetite from those of the siliceous minerals." And he concluded, "it, therefore, seems that the rocks would be not readily amenable to concentration." Spencer's conclusions were correct in 1916, but advances in iron ore beneficiation and drilling technology made since 1916 have succeeded in most kinds of low-grade taconite to iron-ore status.

The largest of the iron deposits in the district is now being developed by the Columbia-Geneva Steel Division, U.S. Steel Corp., whose personnel, for the past few years, have been carrying on a program of exploratory diamond drilling and intensive geologic and magnetic surveying in the vicinity of Iron Mount ain.

In response to the increased public interest in western iron deposits, the U.S. Geological Survey returned to the $\Lambda$ tlantic district in the summer of 1958 to learn more about the deposits which Spencer had outlined in 1916, and nearly 2 months were spent by the writer mapping the area depicted on plate 1 of this report.

The mapping was done by pace and sundial compass methods on a topographic base map (pl. 1) supplied by the Columbia-Geneva Steel Co. Surveyed claim corners, drill-hole locations, and topography were used for control. A magnetic survey (pl. 2) covering most of the area was made concurrently with the geologic mapping using a Sharp D-2 dip needle.

All outcrops known from previous surveys were remapped and examined, and the area mapped was expanded beyond previous limits in order to better show the geologic setting of the iron deposits.

In many particulars, but especially in the general stmucture the geologic map differs markedly from any previous map of the area, but it satisfies most of the field data. 


\section{ACKNOWLEDGMENTS}

I am much indebted to the personnel of the U.S. Steel Corp., and the Columbia Mining Co., for very congenial cooperation, particularly to Messi's. R. H. B. Jones, F. M. Galbraith, and V. Tompkins. Access to company materials, such as base maps, geologic and magnetic maps, drill hole $\operatorname{logs}$, and the like, eased the mapping job considerably, and I am very grateful. Permission to publish the geologic map on their base, and to show the location of diamond-drill holes, was granted by the U.S. Steel Corporation.

\section{GENERAL CONSIDERATIONS}

The location of the iron deposits and the major geologic features of the area are shown on figure 1 . The iron deposits occupy the northwest corner of a large tract (about 100 square miles) of metamorphosed Precambrian sedimentary and volcanic rocks. The metamorphic rocks are flanked on the east and west by granite, on the north by northeastward-dipping, unmetamorphosed Paleozoic rocks, and on the south by nearly horizontal Tertiary rocks. They lie along the crest of the Wind River Range between 7,500 and 8,500 feet above mean sea level, and form a dissected pediment gently inclined (100 $\mathrm{ft}$ per mile) toward the southeast along the anticlinal axis of the range. The maximum local relief in the area, valley to ridge top, is about 700 feet.

Many small streams, tributary to the Sweetwater and Wind Rivers, drain the area ; narrow steep-walled canyons are common.

Grass and sage cover the plains and southward-facing slopes, whereas aspen, willow, and pine cover valley bottoms and northwardfacing slopes.

The best access road into the district is State Route 28 which leads to Lander 25 miles to the north, and to Farson 48 miles to the southeast. The closest railroad is at Lander (fig. 1). 


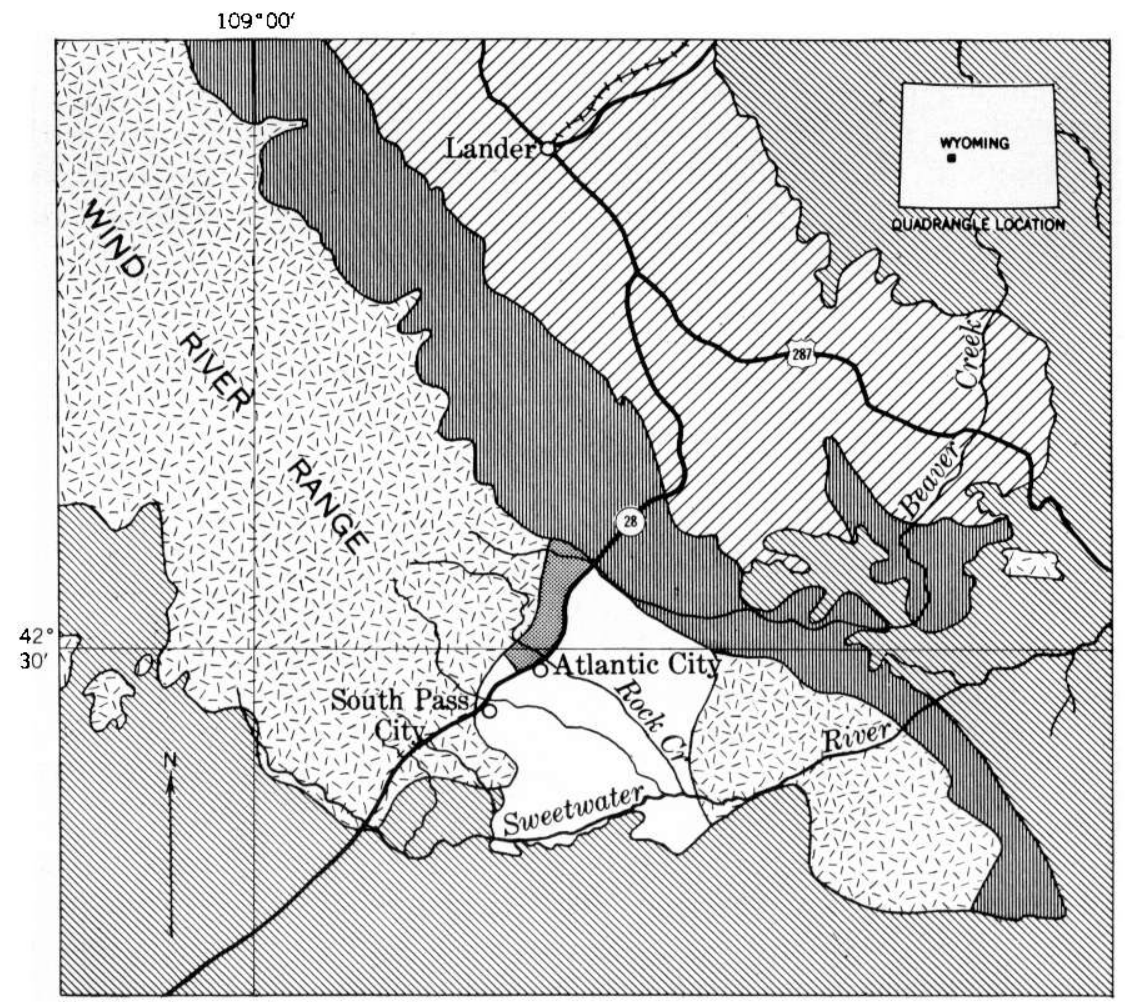

Modified from geologic map of

Wyoming by Love and others (1955)
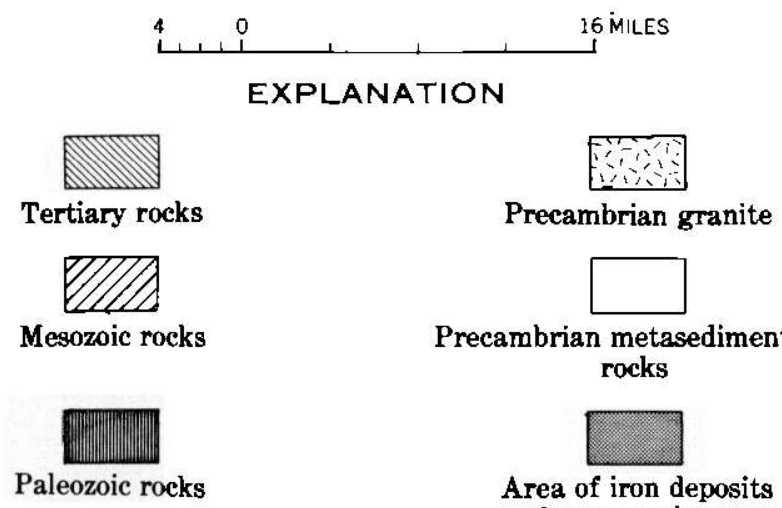

Precambrian metasedimentary rocks

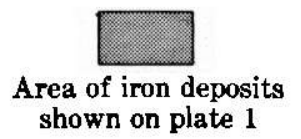

Iigtine 1.-Map showing location and geologic setting of Precambrian iron deposits near Atlantic City, Fremont County, Wyo. 


\section{PRECAMBRIAN METASEDIMENTARY AND METAVOLCANIC ROCKS}

In the mapped area, exposures of the bedded Precambrian rocks show an unbroken but diverse sequence. The sequence is divided, partly on structural grounds, into five informal cartographic units, and the geology of these units is shown on the map (pl. 1); but the development of the structural pattern required the recognition of more and smaller units that are not shown on the map.

A generalized column showing the significant lithologic units used in mapping.

\begin{tabular}{|c|c|c|c|}
\hline \multicolumn{2}{|c|}{ System } & Formation & Character \\
\hline 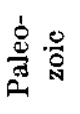 & $\underset{D}{\stackrel{d}{E}}$ & \multirow{2}{*}{$\begin{array}{l}\text { Flathead quartzite } \\
\text {-Unconformity } \\
\text { Intrusive rocks }\end{array}$} & \\
\hline & \multirow{4}{*}{ 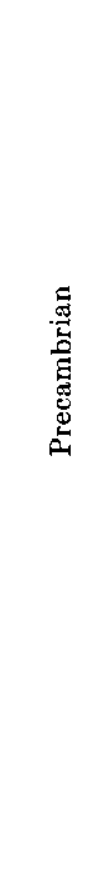 } & & $\begin{array}{l}\text { Granite. } \\
\text { Metadiabase and metagabbro. } \\
\text { Serpentinite (metaperidotite). }\end{array}$ \\
\hline & & $\begin{array}{l}\text { Upper schist } \\
400+\text { feet }\end{array}$ & $\begin{array}{l}\text { Ellipsoidal greenstone. } \\
\text { Greenschist (metavolcanic). } \\
\text { Mica-andalusite schist. } \\
\text { Biotite (chlorite)-garnet schist }\end{array}$ \\
\hline & & $\begin{array}{l}\text { Main iron-formation } \\
140-160 \text { feet }\end{array}$ & $\begin{array}{l}\text { Chlorite garnet schist. } \\
\text { Iron-formation. } \\
\text { Chlorite - amphibole - magnetite- } \\
\text { garnet-schist. }\end{array}$ \\
\hline & & $\begin{array}{l}\text { Lower schist } \\
400 \text { feet }\end{array}$ & $\begin{array}{l}\text { Quartz-mica-andalusite schist. } \\
\text { Quartz-mica schist. } \\
\text { Iron-formation. } \\
\text { Chlorite-amphibole - magnetite- } \\
\text { garnet-schist. } \\
\text { Quartz mica-andalusite schist. } \\
\text { Quartzite. } \\
\text { Mica-andalusite schist. } \\
\text { Feldspathic quartz-biotite schist. }\end{array}$ \\
\hline
\end{tabular}

LOWER SCHIST

The lower schist unit contains a variety of schist types, an extensive and distinctive quartzite unit, and a thin iron-formation unit. These rocks are best exposed between the main iron-formation and the granite in the west central and the southwestem part of the mapped 
area. The areas of the Lower schist unit in the northwestern and northeastern parts of the area are almost entirely inferred.

The metasedimentary schist in the lower part of the division is interlayered as concordant inclusions in schistose and gneissic granite, and with sill-like inclusions of metadiabase and metagabbro. The lower limit of the division has been arbitrarily set where granite is the dominant rock present.

The schist inclusions in granite form long, thin bodies, 10 to 50 feet long and 1 to 10 feet thick, and their attitudes conform almost exactly with those of the adjacent schist that has not been intruded by the granite.

Most of the schist inclusions are light-colored feldspathic quartzbiotite schist. They are well foliated, and show medium-sized eyes of quartz, plagioclase, and relict grains of sedimentary rock, in a fine-grained matrix composed of quartz, plagioclase $\left(\mathrm{An}_{30}\right.$, approx $)$, biotite, and microcline. The plagioclase of the eyes is commonly sericitized and partly replaced by microcline. A small amount of dark-green to black schist is also found interlayered with the granite, particularly near N.689-E.503 ${ }^{1}$ (pl, 1). It is composed entirely of metamorphic biotite, quartz, and untwinned plagioclase.

The schist above the granite, near the base and near the top of the quartzite unit, differs from the schist interlayered with granite in that it is apparently not feldspar bearing. Commonly it contains biotite and muscovite, quartz, and sericite pseudomorphs after andalusite. In most of this schist the biotite has been replaced by chlorite.

The upward change in the rocks, from schist to quartzite and to schist again, appears to be gradational by interlayering.

The quartzite in the lower schist division is a very distinctive mappable unit. Outcrops of quartzite are found chiefly in the western and southwestern part of the mapped area, but a small isolated outcrop of quartzite was found in the northeast corner of the mapped area.

The quartzite is 20 to 40 feet thick. Individual beds range from less than an inch to several feet in thickness. Commonly it is light colored, white to gray, but in some outcrops it appears to be pale bluish green because chrome muscovite (fuchsite) colors the bedding surfaces and forms thin schist layers between the quartzite layers.

The quartzite is very fine grained to fine grained, totally recrystal. lized, and vitreous. It shows no primary sedimentary features other than bedding; in thin section it shows a simple quartz mosaic with numerous minute flakes of colorless mica and a trace of bluish-gray tourmaline between the quartz grains.

\footnotetext{
1 Numbers indicate thousands of feet on State coordinate system.
} 
About 20 to 80 feet above the quartzite, the quartz-mica-andalusite schist grades into chlorite-amphibole-magnetite-garnet schist that contains a few thin metachert layers. This unit in turn grades upward into the lower, banded chert-magnetite iron-formation which is similar to the main iron-formation to be described below. This lower iron-formation is 20 to 60 feet thick, and in the southern part of the area it is continuous along the strike, though contorted and sliced by faults. At a few places, especially in the vicinity of N. 689, the lower iron-formation is represented by two or more thin iron-formation units separated by mica schist. There is no evidence that these lower iron-bearing units extend north of N.690 or south of N.680.

Quartz-mica schist, 20 to 100 feet thick, some of which contains sericitized andalusite, overlies the lower iron-formation; this schist grades upward and is interlayered with chlorite-amphibole-magnetitegarnet schist that forms the basal part of the main iron-formation. Some of the quartz-mica schist is almost entirely chloritized; part of it contains green biotite and remnants of brown biotite, which indicates that biotite was probably the original metamorphic mineral in all of the schist. In places the schist is dark gray and slightly carbonaceous.

Andalusite occurs in the quartz-mica schist described above in peanutlike forms, up to $1 \mathrm{~cm}$ long and 2 to $3 \mathrm{~mm}$ wide; it shows elongation parallel to axes of minor folds. Nearly all crystals are sericitized, and the sericite pseudomorphs contain concentrations of carbonaceous dust, but the dust does not show a zonal arrangement as in chiastolite.

Near the base of the main iron-formation, thin beds of magnetite and metachert are interlayered with quartz-chlorite schist, chloritegarnet schist, and chlorite-amphibole-garnet-magnetite schist. These selvage rocks are well foliated and show a strong alinement of metamorphic quartz, chlorite, and amphibole. The larger quartz grains form augen, whereas the garnet porphyroblasts transect the foliation. The garnet in some specimens is completely replaced by a cryptocrystalline aggregate composed of a mineral resembling chlorite. Some of the schist, composed mainly of chlorite, shows areas of remnant biotite. The amphibole in the schist ranges from common bluegreen hornblende to nearly colorless grunerite. Weathered grunerite-bearing schist commonly shows limonite alteration, in contrast with weathered quartz-magnetite iron-formation which generally shows hematite alteration.

Near the north end of the map, the rocks of the lower schist division crop out only on the east slope of the little valley that separates the small transverse syncline and the main southward-trending syncline, and on the east side of the main syncline (pl. 1). The rocks between 
the synclines are red, oxidized garnet schist, whereas the rocks east of the main syncline are green schist derived from mafic volcanic rocks, and quartzite. The occurance of the volcanic rocks, between the main iron-formation and the quartzite of the lower schist division, suggests that they were deposited at the same time as the sedimentary schists that occupy the same stratigraphic position to the south.

\section{MAIN IRON-FORMATION}

The distribution of the main iron-formation is shown on the bedrock map (pl. 1). All known outcrops are shown. Where outcrops are lacking, the distribution is controlled by the magnetic survey as shown on plate 2. Areas of no outcrop are covered by talus and alluvium, at places, more than 200 feet thick. Recent (1959) diamond drilling carried out by the J. R. Simplot Co., to locate iron-formation in the areas of no outcrops shown on plate 1 , has verified the distribution of the iron-formation as inferred from magnetics.

The main iron-formation is chiefly dense, hard, laminated rock, composed principally of quartz, magnetite, and amphibole. The layers commonly show plications (fig. $2 \mathrm{~A}$ ), and range in thickness from less than $1 \mathrm{~mm}$ to more than $6 \mathrm{~cm}$, but layers $1 \mathrm{~mm}$ to $1 \mathrm{~cm}$ are most common (fig $2 B, C$ ). Magnetite-rich layers alternate with quartz-rich layers, or rarely, jasper layers (fig. $2 B$ ).

The rock is generally graly or black, and is fine grained; the microtexture is hornfelsic. The quartz layers, which presumably were originally chert, are fine-grained quartz mosaics with intergranular euhedral magnetite and amphibole; the magnetite layers contain chiefly euhedral magnetite and chrystalline magnetite aggregates, but also contain a few quartz grains and amphibole euhedra (fig. 2, $E$ and $F$ ). For 10 specimens examined, the average size of quartz and magnetite crystals is 0.2 and $0.12 \mathrm{~mm}$ respectively. The coarsest material was found near the granite in the northwest corner of the mapped area.

The amplibole in the iron-formation is generally colorless, but pale bluish-green in some specimens and pale bluish-gray in others. It has a large $(-) 2 \mathrm{~V}$, and the extinction angles $\mathrm{Z} \wedge \mathrm{c}$ range from nearly zero to $22^{\circ}$, the greater angles being most common. It weathers to limonite and a colorless chlorite or clay mineral. Some of the amphibole is probably gruenerite $\left(\mathrm{H}_{2} \mathrm{Fe}_{7} \mathrm{Si}_{8} \mathrm{O}_{24}\right)$, but the clay alteration suggests that some of it contains the alumina-bearing hornblende molecule as well. Apatite, biotite, chlorite, and garnet are present in the main part of the iron-formation in only trace amounts.

Modal counts of 10 representative samples of the main iron-formation show that magnetite $(72.4$ percent $\mathrm{Fe})$ and quartz are about 
equally abundant and together make up 90 percent or more of the rock. The indicated average $\mathrm{Fe}$ content of the 10 samples therefore is 32 percent, or a little more. The average specific gravity of the 10 representative samples is 3.4 .
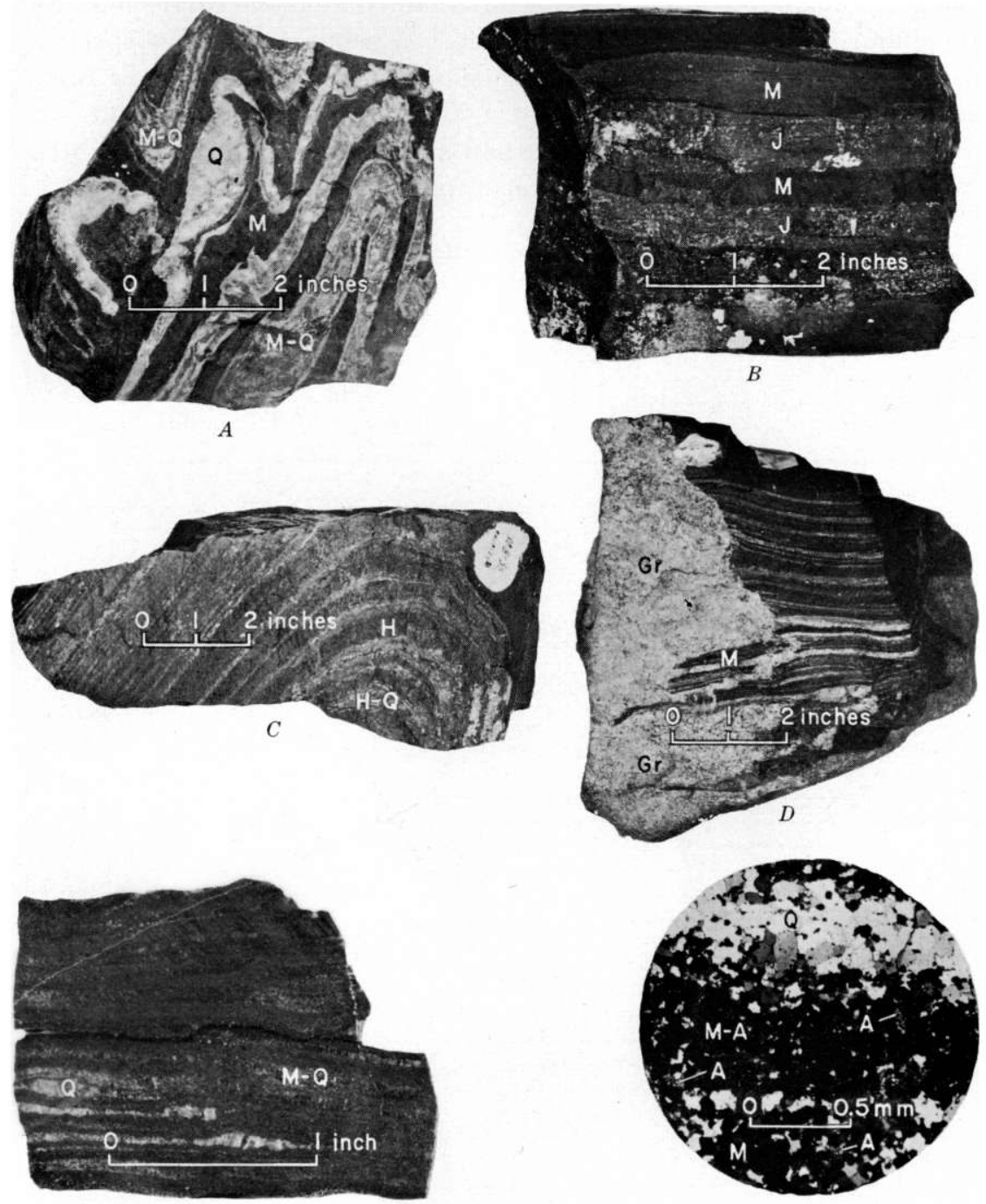

$E$

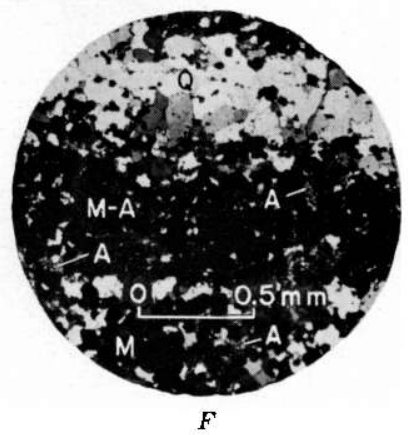

Figure 2.-Photographs of iron-formation specimens. A, Contorted quartz-magnetite ironformation: $B$, Banded jasper-magnetite iron-formation: $C$, Oxidizal quartz-magnetito iron-formation, now quartz-hematite; $D$, Laminated quartz-magnetite iron-formation nartly replaced by granite; $F$, Sawed section of laminated quartz-magnetite iron-formation: $F$, Photomferosraph of part of $E$; $A$, amphibole; Gr. granite; $H$, hematite imartite) ; J, jasper : II, mignetite; Q. quartz (metachert). 
Chemical analyses of iron-formation available for publication at this time are four analyses from Spencer (1916, p. 18) in columns 1 to 4 below, and one new analysis by Dorothy F. Powers of the U.S. Geological Survey, recomputed for comparison with the four older analyses, shown in column (5). The standard analysis corresponding to column (5) is given below the table. A semiquantitative spectrographic analysis for 46 elements made on this sample shows the presence of trace amounts of $\mathrm{Ba}, \mathrm{Cr}, \mathrm{Cu}, \mathrm{Ga}, \mathrm{Ni}, \mathrm{Sr}$, and $\mathrm{Yb}$. Tike the samples for Spencer's analyses this new sample was chipped from beds across about 200 feet of outcrop at approximately the same locality.

Partial chemical analyses of iron-formation, Atlantic district, Wyoming

\begin{tabular}{|c|c|c|c|c|c|}
\hline & 1 & 2 & 3 & 4 & 5 \\
\hline 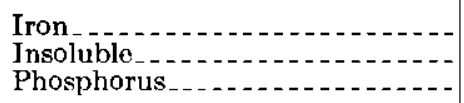 & $\begin{array}{l}42 \\
42 \\
.037\end{array}$ & $\begin{array}{l}43 \\
40 \\
.030\end{array}$ & $\begin{array}{l}39 \\
46 \\
\quad .020\end{array}$ & $\begin{array}{l}27 \\
47 \\
.031\end{array}$ & $\begin{array}{r}29 \\
171 \\
.02\end{array}$ \\
\hline
\end{tabular}

1 Other.

Samples collected on Iron Mountain near Rock Creek. Samples weighing 5 to 7 ibs. were taken by chipping across ledges at intervals of about $2 \mathrm{ft}$.
1. Represents about $180 \mathrm{ft}$ of rock.
2. Represents about 150 ft of rock.
3. Represents about $180 \mathrm{ft}$ of rock.
4. Represents about $250 \mathrm{ft}$ of rock.

Chemical analysis of iron-formation from sec. 23, T. 30 N., R. $100 \mathrm{~W}$. Fremont County, Wyo.

[Dorothy F. Powers, analyst]

Percent

$\mathrm{SiO}_{2}$ 56. 23

$\mathrm{Al}_{2} \mathrm{O}_{3}$ 45

$\mathrm{Fe}_{2} \mathrm{O}$

34. 96

$\mathrm{MeO}$

5. 67

$\mathrm{MaO}$

1. 13

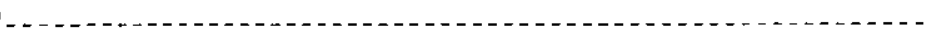

$\mathrm{Na}_{2} \mathrm{O}_{-}$

$\mathrm{K}_{2} \mathrm{O}$

$\mathrm{H}_{2} \mathrm{O}+\mathrm{H}_{-}$

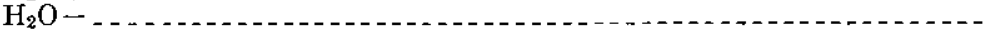

$\mathrm{TiO}_{2}$

$\mathrm{P}_{2} \mathrm{O}_{5}$

$\mathrm{MnO}$

.81

.15

.12

.49

.03

.02

.05

$\mathrm{CO}_{2}$

Cl

F

S.

Total

With respect to the new analysis (5) and many new analyses made by the Columbia-Geneva Steel Co., the Fe average of Spencer's analyses appears too high, although his individual $\mathrm{Fe}$ values fall within the range of $\mathrm{Fe}$ values covered by the new analyses. Tonnage and assay figures given by Mining World (1960, p. 27) are, 300 million tons (indicated ore) assaying 21.8 to 35.2 percent $\mathrm{Fe}$, and $121,200,000$ 
tons (proved reserves) assaying $28-32$ percent $\mathrm{Fe}$. The average $\mathrm{Fe}$ content of the iron-formation probably is close to 30 percent.

The premetamorphic mineral composition of the iron-formation can only be guessed. The small amount of secondary silicate minerals in the rock suggests that the original iron-formation consisted of chert, diagenetic magnetite, a small amount of iron carbonate, and clay as a minor constituent. If this is true, the metamorphism has merely coarsened the grain size of the main constituents, and produced new silicate minerals from the minor constituents.

\section{UPPER SCHIST}

This division lies above the main iron-formation, between the limbs of iron-formation that define the main southwestward-trending syncline (pl.1).

Close above the main iron-formation, the rocks are biotite or chlorite schist similar to the rocks underlying the main iron-formation, as described in the section on the lower schist. Some of the schist beds contain garnet and are interlayered with thin beds of magnetite and beds of metachert which decrease in number away from the ironformation. These transition rocks are as much as 60 feet thick in the vicinity of Iron Mountain, but are absent in the northern part of the area. The top of this chloritic schist zone is marked by biotite or chlorite schist that contains abundant garnet crystals, 1 to $2 \mathrm{~mm}$ in diameter, which stand out on the weathered cleavage surfaces of the schist and give it a raspy feel. This rock is overlain by a mica-andalusite schist unit, which is 40 to 80 feet thick near Iron Mountain, but absent to the north. The mica-andalusite schist is similar to schist beneath the main iron-formation already described.

The remaining part of the upper schist division is greenstone (altered mafic volcanic rock); consisting of vesicular lavas in the lower part, tuffaceous rocks in the middle part, and pillow lavas in the upper part.

The greenstone is strongly sheared, and the pillows form torpedolike bodies which plunge $75^{\circ}$ to $80^{\circ} \mathrm{SW}$. Even though the pillows are elongated many still show tops of beds by their convexities, and near N.689-E.505 it was possible to determine the approximate location of the trough of the main syncline using this criterion.

Vesicular greenstone and laminated tuffaceous greenstone directly overlie the main iron-formation in the outcrop area north of Beaver Creek; the andalusite and garnet schists that form the lower part of the upper schist division in the vicinity of Iron Mountain are absent. On the west limb of the main syncline, in the outcrop area near N.690-E.504.4, sheared greenstone lies immediately above the main 
iron-formation, but it pinches out within a few hundred feet to the south and chlorite-garnet schist takes its place. Similar sheared greenstone is present immediately above the main iron-formation on the south limb of the main syncline in the southern part of the same outcrop area, but it is not exposed farther south.

All the volcanic rocks are now amphibolites or hornblende schists. They are composed chiefly of pale blue-green hormblende, quartz, untwinned plagioclase, epidote group minerals, and chlorite. Sheared vesicular greenstone on the east limb of the main syncline near the iron-formation at N.689-E.505 contains colorless metamorphic pyroxene (probably diopside), blue-green hornblende, zoisite, and quartz.

The metamorphic mineralogy of the greenstones suggests that they are probably altered basalt.

The maximum thickness of the upper schist division in the present map area is about 400 feet, but geologic mapping now under way in areas east of the present map area indicates that the division may be more than 5,000 feet thick.

\section{PRECAMBRIAN INTRUSIVE ROCKS}

Three intrusive rock types cut the metasedimentary and metarolcanic rocks of the area. $\Lambda$ sill-like body of serpentinite is thought to be the oklest, but the field evidence is not conclusive. IDikes of metagabbro and metadiabase are next oldest, and batholithic granite is the youngest. Sparse aplite and pegmatite dikes which lie close to the edge of the granite, and which cut the granite and the adjacent metasedimentary rocks as well, are thought to represent a late-cooling phase of the granite.

\section{SERPENTINITE}

$\Lambda \mathrm{n}$ asbestos-bearing serpentinite body, possibly metaperidotite, forms a sill-like body about 200 feet thick near the base of the quartzite unit of the lower schist division. The main body of serpentinite is west of Iron Mountain, but minor bodies, probably dislocated from the main body by faulting, or isolated from it by the intrusion of younger metauabbro, crop out both north and south of Iron Mountain (pl. 1).

The bulk of the rock is massive, reddish-brown-weathering serpentinite that contrins disseminated magnetite. Less abundant, but important, rock types are black and gray magnetic serpentinite, crysotile asbestos-bearing serpentinite, and serpentine and talc schists.

The black and gray magnetic serpentinites, that possibly represent gravity segregations, appear to be chiefly confined to a narrow zone close to the quartzite - that is, near the east margin of the serpentinite, 
and this zone of magnetic rocks is repeated by faulting in at least the four easternmost of the fault slices shown on the map.

The crysotile asbestos-bearing rock is found extensively throughout the outcrop area of the serpentinite, but natural exposures are rare. It is best known from the dump of an abandoned asbestos mine at N.685.6-F.500.7, and from the dumps of many test pits in the same area. The rock is variable in color and texture. Shades of green are most common but some parts are blue-gray or nearly black. Some of it is intensely sheared whereas part of the rock is massive. Cross-fiber crysotile forms discontinuous, subparallel veinlets through the rock, commonly three or more to the inch. Veinlets less than a quarter inch in width are the rule, but veins 1 inch in width are not uncommon. Fine-grained crystalline serpentine makes up the bulk of the rock. The crysotile-bearing rock seems to be limited to shear zones in the serpentinite body, but this conclusion is based on very few observations.

The serpentine and talc schists are best developed close to the quart zite of the southeast margin of the main serpentinite body, but they also are found throughout the serpentinite exposures at the south edge of the mapped area. The schists are dark green, soft and soapy, and contain tiny disseminated crystals of magnetite.

The age of the serpentinite with respect to the metadiabase and metagrabbro dikes could not be determined conclusively. Isolated exposures of metadiabase are found in the main serpentinite mass west of Iron Mountain, the location of which could be explained as well by faulting as by intrusion ; on the other hand, the apparent termination of the serpentinite and quartzite to the north of the main body near N.686-E.501.5 suggests that both were interrupted by intrusive metadiabase.

\section{METADIABASE AND METAGABBRO}

Metamorphosed mafic dikes, probably diabasic gabbro originally, cut all of the Precambrian rock units of the area except the granite, and possibly the serpentinite. They are sill-like and nearly concordant with the enclosing rocks at most places, but locally they cut sharply across the enclosing rocks. They appear to occupy oblique fault zones, but not the zones of late transverse faults; they are commonly sheared, and therefore definitely antedate at least one period of strong deformation. Thin dikes are generally well foliated hornblende schist, whereas thicker dikes are hornfelsic, or show relict igneous texture in their interiors, and are mantled by hornblende schist.

If there is only one set of mafic dikes, and this is impossible to know, then an overall view of their pattern in the mapped area suggests that they were emplaced after some folding had taken place. The reason 
for this conclusion is probably best illustrated by the dikes on Iron Mountain, near N.684-F.502. These dikes bulge in the relatively incompetent upper schist, and send out thin unfolded streamers into folded iron-formation. The streamers cut the main iron-formation nearly perpendicularly to the crenulated bedding, and nearly parallel to the axial planes of the crenulations-the direction of slip cleavage.

The mafic dike rocks are dark green to nearly black, and fine to coarse grained. They are composed chiefly of hornblende, palegreen and slightly fibrous where the dikes lie some distance away from the granite front, and dark blue-green and well crystallized where the dikes lie close to the granite front or are inclusions within the granite. The dikes away from the granite also show remnants of a complexly twinned and sericitized plagioclase, the composition of which is approximately $A n_{35-40}$. In dikes close to the granite, or in inclusions of dike rock within the granite, the original plagioclase is lacking, and a new untwinned, granoblastic plagioclase (composition unknown) is present. Quartz is present in minor amounts, and the accessory minerals are sphene, magnetite, and apatite. Judging from the present metamorphic mineral makeup of these rocks, and from their field appearance, they are probably gabbroic.

\section{GRANITE}

Batholithic granite flanks the Precambrian metamorphic rocks on the west and northwest. It is intrusive and, aside from sparse pegmatite and aplite dikes, it is the youngest igneous rock observed. The contact is commonly marked by a broad zone, up to 1,000 feet wide, in which schistose granite, inclusions of schist of sedimentary origin, and schistose metadiabase are interlayered.

The gneissic contact zone is present along the granite front from Rock Creek northeast at least to N.690-F.503 where the exposures end. In the northernmost part of the area the broad contact zone is absent. Relatively massive granite is in contact with the main iron-formation, and sharp-walled stope blocks of iron-formation are contained in the granite. Southwest of Rock Creek the layered gneiss zone does not mark the contact between the granite and the metasedimentary rocks but continues on strike southwest into granite terrane where it separates the southeastward-protruding mass of granite south of Rock Creek from the main mass of granite to the northwest.

There is no layered gneiss zone along the granite-metasediment contact of the south lobe of granite. The absence of this zone suggests that the granite of this south lobe was intruded a little later than the main mass of the granite northwest of it, and that it was intruded 
between already formed layered contact gneiss and the host metasedimentary rocks. A similar but smaller body of granite was intruded above the main iron-formation near N.690-E.504, although the main contact zone of the granite is below and roughly concordant with the quartzite as shown on the map at N.689-E.503 (pl. 1).

The granite is generally light colored; some of it is almost white. It is medium to coarse grained, massive and equigranular to somewhat porphyritic and gneissic (augen gneiss). The chief minerals are microcline and albite-oligoclase, about equally abundant, and minor accessary minerals are biotite (or, if altered, chlorite), muscovite, epidote, clinozoisite, zircon, sphene, tourmaline, and allanite. Granite is the field term for these rocks. Some of the rock sampled is granite, but some is granodiorite or quartz monzonite.

In the northern part of the area where relatively massive granite and the main iron-formation are close together, quartz veins and aplitic and pegmatitic dikes cut the granite and the iron-formation. The dikes are microcline rich, and probably represent a late crystallizing phase of the granite. Within the granite they are generally located on gentle, northwest-dipping joint surfaces. They commonly show replacement phenomena on a small scale where they cut iron-formation (see fig. $2 D$ ).

The granite is believed to be a magmatic intrusive for the following reasons:

1. It has intimately disrupted the country rock.

2. Angular stoped blocks of iron-formation lie deep within it.

Though magmatic, the granite is believed to have been almost completely crystallized and extremely dry at the time of intrusion because: (a) all the deformational structures in the granite appear to have been developed after crystallization, (b) granite dykes cutting the country rock are extremely rare, and (c) the country rocks have not been altered metasomatically as they probably would have been, had the granite been intruded as liquid magma.

\section{PALEOZOIC ROCKS}

\section{FLATHEAD QUARTZITE OF MIDDLE CAMBRIAN AGE}

The Flathead quartzite is a remarkably persistent formation of conglomerate, sandstone, and quartzite that marks the base of the Paleozoic section throughout a large area in Wyoming and Montana. The type locality of the formation is at Flathead Pass in the northeast corner of the Threeforks quadrangle, Montana (Peale, 1893, p. 20-22).

Although the Cambrian age of the basal Paleozoic rocks of the Wind River Range was recognized very early, the name Flathead 
was probably first applied to these rocks by Condit $(1924$, p. 7$)$ who believed them to be of Middle Cambrian age. Branson and Branson $(1941$, p. 125$)$ also assigned these rocks to the Middle Cambrian, but chiefly because they underlie and grade up into the fossiliferous Gros Ventre formation of Middle Cambrian age. The Flathead quartzite itself is not fossiliferous at most places.

In the northern part of the mapped area, the Flathead quartzite rests unconformably on the Precambrian rocks. The formation strikes northwest, parallel to the core of the Wind River Range, and $\operatorname{dips} 12^{\circ}$ to $20^{\circ} \mathrm{NE}$. It is succeeded on the northeast by younger Paleozoic rocks, and by Mesozoic and Tertiary rocks.

Sandstone and conglomerate are the principal rock types. These are thick and thin bedded, and commonly are crossbedded. Most of the rocks are pink to reddish brown, but some are nearly white.

Conglomerate beds are interspersed in the formation, and these contain chiefly well rounded quartz pebbles as much as 1 inch in diameter. Conglomerates near the base of the formation, in addition to the quartz pebbles, contain detritus derived from immediately below them, therefore they vary in makeup from place to place. Where the formation rests on granite or gneiss, the basal rocks are arkosic conglomerate which contain fragments of salmon-colored feldspar as well as the usual quartz pebbles.

Condit $(1924$, p. 7$)$ gives the thickness of the Flathead for this general area as 300 feet.

\section{STRUCTURE}

FOLDING

A principal southwestward-trending syncline dominates the Precambrian structures within the mapped area (pl. 1). The syncline is roughly $13 / 4$ mile long and $1 / 2$ mile wide. It hinges near the north border of the map in an area of southwestward-plunging subordinate folds. It opens out and loses its identity as a syncline near N.686E.504, where the east limb swings to the east forming a blunt anticlinal nose. And from this point, the west limb continues southwest as a steeply dipping homocline.

The limbs of the syncline are steeply dipping; rertical beds are common, and overturned beds occur on the east limb at a few places. Schist in the trough of the syncline shows a strong foliation which strikes northeast and dips $70^{\circ}$ to $85^{\circ} \mathrm{SE}$. The southeast dip is consistent across the syncline, indicating that the axial plane of the syncline probably dips similarly. Lineations on the foliation surfaces, caused by the elongation of mineral pods, rock fragments, and lava pillows, plunge $70^{\circ}$ to $85^{\circ} \mathrm{SW}$. The pillows are elongated $3: 1$ to $5: 1$. 
Drag folds and crenulations, which are most abundant in the ironformation (fig. $2 A, C$ ), strike at a slight angle to the bedding and plunge toward the trough of the syncline at high angles, as much as $90^{\circ}$. Mineral alinement in these minor folds, such as stretched andalusite crystals, is parallel to the fold axes. The above features suggest a strong near vertical stretching, up or down the dip of the foliation planes, and in the plunge directions of the minor folds. Boudinage seen in cross sections of the iron-formation suggest the same thing. The steep limbs and the steeply pitching minor folds suggest as well, that the syncline is very deep. For example, in that part of the syncline that lies between the two transverse faults (pl. 1), the depth to the main iron-formation in the trough may be as much as 4,000 feet, assuming that the limbs dip toward each other at a constant $80^{\circ}$

It was mentioned above that the principal syncline terminates where the east limb turns southeast to form an anticlinal nose. It has been possible to demonstrate only half of this anticline. The outcrop of the southeastward-trending iron-formation ends 400 feet northwest of State Route 28 ; a magnetic anomaly that marks the trend of the ironformation under the surficial cover extends beyond the outcrop to a point 300 feet southeast of the highway where it ends abruptly. Mapping now in progress to the southeast beyond the limits of the present map indicate that the iron-formation has probably been truncated by a major northeast ward-trending fault.

A small overturned syncline set transversely to the principal northeastward-trending syncline is in the northwestern part of the mapped area. It is about 2,000 feet long and about 600 feet wide. Both north and south limbs dip south, the south limb is overturned; and both the east and west hinges plunge east, and the east hinge is overturned. The plunge of minor folds on the overturned east hinge is the same as the dip of the west limb of the adjacent principal syncline, and the same as the dips of the axial planes of secondary folds in the hinge of that syncline.

The very narrow corridor between the synclines is thought to be too narrow to contain an anticline; hence on the map, the synclines are shown separated by an inferred reverse fault with upward motion on the east side. The overturn of the beds on the east end of the small syncline could have been caused by drag on such a fault.

\section{FAULTING}

Faults of two ages have been noted, an older suite of oblique faults nearly parallel to the main northeastward-trending syncline, and a younger suite of transverse faults. 
Faults of the older suite slice across the Precambrian metasediments at low angles, but aside from their map expression, not very much is known about them. In a particular area, for instance the Iron Mountain area, the faults occur in semiparallel groups; they strike northeast and dip southeast at steep angles (see $A-A^{\prime}, \mathrm{pl} .1$ ). The movement on the faults is apparently reverse, east side up, with the amount of upward movement increasing toward the southeasternmost faults of the group, so that the affected rocks are imbricated and greatly overthickened. For instance, the serpentinite body northwest of Iron Mountain is repeated 7 or 8 times, and the main iron-formation, which has a thickness of only 150 feet both north and south of Iron Mountain, has been expanded to nearly 1,200 feet in thickness by a combination of folding and imbricate faulting at Iron Mountain. Along two major reverse faults on Iron Mountain, near N.683.2E.501.2, the rocks of the lower schist division have been brought in contact with rocks of the upper schist division, thus repeating large segments of iron-formation, which are themselves imbricated. Principally because of the faulting, the amount of iron-formation available to opencut mining has been increased nearly tenfold.

Several faults of the older suite offset segments of the granite lobe south of Rock Creek. It has not been possible to trace the faults into the granite, but the relations at the margin of the granite seem conclusive.

The intent and purpose of this preliminary statement do not permit any further discussion of this suite of faults. Many of them have not been mentioned at all, but, in a general way, the remarks and conclusions stated above may be applied to most of them.

The second, younger suite of faults is represented by two large transverse breaks along which the principal syncline has apparently been offset (pl. 1). They appear to me to be normal faults, north side down, but other interpretations are possible.

Facts and conclusions bearing on the age of the folding relative to the time of faulting and the intrusion of the igneous rocks are summarized below :

1. Some or all of the folding took place before the intrusion of the metadiabase dike swarm, because unfolded dikes cut folded ironformation.

2. The granite cuts the metadiabase dikes, and the folding, therefore, must predate the granite.

3. At the west end of the small syncline in the northern part of the area, relatively massive granite that shows only a feeble mica lineation, and small aplite and pegmatite dikes spawned of the granite, cut folded iron-formation, further documenting (2) above. 
4. The map pattern shows that the large transverse faults postdate the folding, but there is no obvious time relationship between many of the older suite of oblique faults and the folding. Many of the oblique faults contain sheared metadiabase dikes. These dikes, as noted above, at places, cut folded iron-formation. Two possible relationships are evident. First, faults developed in the iron-formation and other rocks at the time of folding provided loci for the intrusion of the metadiabase dikes. Renewed movement on the same faults caused shearing of these dikes. Other oblique faults related to somewhat later movements, but not containing dikes, caused large offsets on some of the metadiabase dikes, as at N.684.5-E.500.5. Secondly, all the oblique faulting was late with respect to the intrusion of the metadiabase dikes, which, in general, controlled the locations of later faults. I favor the first of the two possible relationships. In either case, the granite, which postdates the intrusion of the metadiabase dikes, must have been involved in slightly later oblique faulting-and it definitely was, as the geologic relationships along Rock Creek attest.

\section{METAMORPHISM}

I do not propose to outline the metamorphic history of the district on the basis of the observations made in the very limited area mapped so far, but I shall attempt to summarize all the pertinent facts now known.

1. All the Precambrian rocks show the effects of metamorphism.

2. Two ages of metamorphism are evident. The older is moderate regional metamorphism, which produced epidote-amphibolite and amphibolite facies rocks; and the younger is retrograde metamorphism, which produced greenschist facies rocks from the earlier formed metamorphic rocks.

3. In the small area examined, the thermal gradient, as indicated by the metamorphic minerals, increases toward the granite. The sharp increase in gradient is confined to a narrow zone at the granite margin within the confines of the mapped area. As far as is known there is no gradient perceptible beyond the limits of the mapped area. Possibly the granite intruded rocks already metamorphosed regionally.

4. The fine-grained character of the metamorphosed rocks seems unusual, considering the facies, and possibly indicates that the first metamorphic episode had a relatively short duration.

5. The crystal edges of such minerals as garnet and andalusite cut across an earlier formed mica foliation. Some crystals so formed were later deformed and alined in the plane of the original foliation, 
indicating to me that deformation along similar planes both preceded and followed the formation of the porphyroblasts.

6. Both schistose and hornfelsic rocks occur side by side in the area. In the case of the metadiabase dikes, the thickness of the dikes appears to have been the controlling factor-thin dikes ( a few inches to a foot thick) are completely sheared whereas thick dikes are schistose outside but holnfelsic inside. For the metasedimentary rocks, the ability or inability of the rocks to form micaceous or acicular minerals, to a large extent, appears to have controlled the fabric.

7. Although some metasedimentary schist and metadiabase are interlayered with gneissic granite in the contact zone, evidence of metasomatic alteration is uncommon. Microcline found in the inclusions of lower schist in the contact zone is assumed to indicate metasomatism, because similar schist not included in the granite does not contain microcline. However, the metasomatic effects of the granite are unimportant; apparently the granite was nearly dry, and probably mostly crystallized before reaching its present level.

8. Widespread retrograde metamorphism, that indicates conditions commensurate with greenschist facies metamorphism, has affected most of the rocks metamorphosed previously at higher temperatures, and the intrusive granite as well. The downgrading of the minerals, although widespread, is generally spotty and incomplete; remnants of minerals indicate the original metamorphic character of the rocks persist in almost all specimens examined. The retrograde effects in the granite, chiefly the sericitization of plagioclase and the chloritization of biotite, might be considered automorphic or deuteric. If the agents of such alterations were free to enter the neighboring metasediments, similar minerals changes could be expected. Therefore, both the high- and the low-temperature phases of the metamorphism that affected the sedimentary and mafic igneous rocks of the area may be dependent on their proximity to the granite.

To summarize briefly, the original metamorphism was moderate and regional, but showed a sharp rise in gradient very close to, and within, the granite contact zone. Later retrograde metamorphism caused a general downgrading of the minerals in previously formed metamorphic rocks and of minerals in the granite as well. Both high and low phases of the metamorphism may stem from the granite.

Undoubtedly more facts bearing on the metamorphism of the rocks of the district will come to light as the geologic investigation progresses. 


\section{MAGNETIC SURVEY}

In conjunction with the geologic mapping, a magnetic survey was made that covers a large part of the area. The survey was intentionally confined to areas where outcrops are scarce or the structure indeterminable from observations made on outcrops.

$\Lambda$ dip needle was used; and because the anomalous magnetism in the area required traversing by sun compass, declination readings were made at many places. The results of the magnetic survey are summarized on plate 2 . These magnetic data were used extensively in determining the structure of the iron-formation shown on the geologic map. Three critical areas where the magnetic survey helped to define the structure are:

1. At the junction of the adjacent synclines in the north part of the map, at N.693.4-E.505.4, where the survey shows separate anomalies for limbs of the adjacent synclines, one trending south, and the other trending west.

2. In the areas of the transverse faults that cut the principal syncline. Along the fault, closed anomalies that indicate truncated iron-formation are well defined.

3. In the southern part of the area, repetition by faulting of the thin iron-formation in the lower schist division and the left-lateral displacement of the main iron-formation at N.682-E.502 are well defined by the magnetic survey.

Local variations from the regional magnetic declination (about $16^{\circ} \mathrm{E}$.) are most interesting in that in this area they invariably point the way to the closest iron-formation even where it is deeply covered. Declination reading from the sun compass therefore offers a very quick and cheap method of surveying for this and possibly for other magnetic iron-formation.

\section{MINERAL DEPOSITS}

\section{IRON}

In the area mapped iron is abundant in the form of siliceous magnetic taconite. The taconite contains only about 30 percent iron, but it is amenable to concentration by magnetic means. Examination of this material shows that it contains about equal amounts of magnetite and quartz, and a minor amount of amphibole, chlorite, and garnet. The amount of silicate minerals increases toward both the top and the bottom of the main iron-formation.

As Spencer (1916) recognized, most of the material is of a grain size which will require fine grinding to release the grains of magnetite from the matrix.

$6590990-63-2$ 
In almost every outcrop area, some of the iron formation is hematitic or limonitic (oxidized in the zone of weathering) and is nonmagnetic or only weakly magnetic, and therefore is not amenable to beneficiation by magnetic methods alone.

The continuity along strike and the steep dip of the iron-formation beds, and diamond drilling already completed, insure safe extrapolation of surface conditions to a great depth at most places-at least below the practical limits of open-pit mining. The topography at most places is eminently favorable for open-pit mining in that the iron-formation makes the topographic highs.

The only very large concentration of iron-formation is at Iron Mountain, where developmental work is being done by the ColumbiaGeneva Steel Co. whose plans include a large open-pit mine. Ten smaller but important concentrations of iron-formation lie northeast and southwest of Iron Mountain within the map area. Full utilization of this iron reserve will require the operation of a series of small scale open-pit mines along the length of the iron range over and above the intended mine at Iron Mountain.

\section{ASBESTOS}

Short-fiber serpentine asbestos (chrysotile) occurs in shear zones at many places in the serpentinite body on the west slope of Iron Mountain. A number of test pits scattered about the body, and an adit entering the body from the west side near N.685.5-E.5\%).5, have penetrated sheared serpentine rock containing chrysotile veinlets, 2 to 4 to the inch, as much as half an inch thick. The exploration pits are at the narrow north end of the body; the broad south part has not been adequately explored. The repeating of the serpentinite along faults as shown on the map, must have produced shear zones, none of which have been explored, and some of which may contain quantities of asbestos.

\section{GOLD}

Gold-bearing quartz veins, or quartz veins of any kind, are rare in the area mapped, and the few veins that were found do not seem to be mineralized. $\Lambda$ small amount of gold was produced from the vein shown at the southeast edge of the mapped area. $\Lambda$ shallow opencut on the vein was called Lone Star Mine by the owner, Mr. Birch of South Pass Route, Fremont County, Wyo., who told me that the quartz vein assayed about $\$ 2$ per ton. The ore was processed in a small stamp mill on Rock Creek, now abandoned. 


\section{REFERENCES CITED}

Branson, E. B., and Branson, C. O., 1941, Geology of Wind River Mountains, Wyoming: Am. Assoc. Petroleum Geologists Bull., v. 25, no. 1, p. 120-151.

Condit, D. Dale, 1924, Phosphate deposits in the Wind River Mountains, near Lander, Wyoming: U.S. Geol. Survey Bull. 764, 39 p.

Love, J. D., Weitz, J. L., and Hose, R. K., 1955, Geologic mup of Wyoming: U.S. Geol. Survey.

Mining World, 1960, Wyoming taconite project to get underway : Mining World, v. 22 , no. 8 , p. 27, July 1960 .

Peale, A. C., 1893, The Paleozoic section in the vicinity of Three Forks, IIontana: U.S. Geol. Survey Bull. 110, 56 p.

Spencer, A. C., 1916, The Atlantic gold district and the north Laramie Mountains, Fremont, Converse, and Albany Counties, Wyoming: U.S. Geol, Survey Bull. 626, 85 p. 



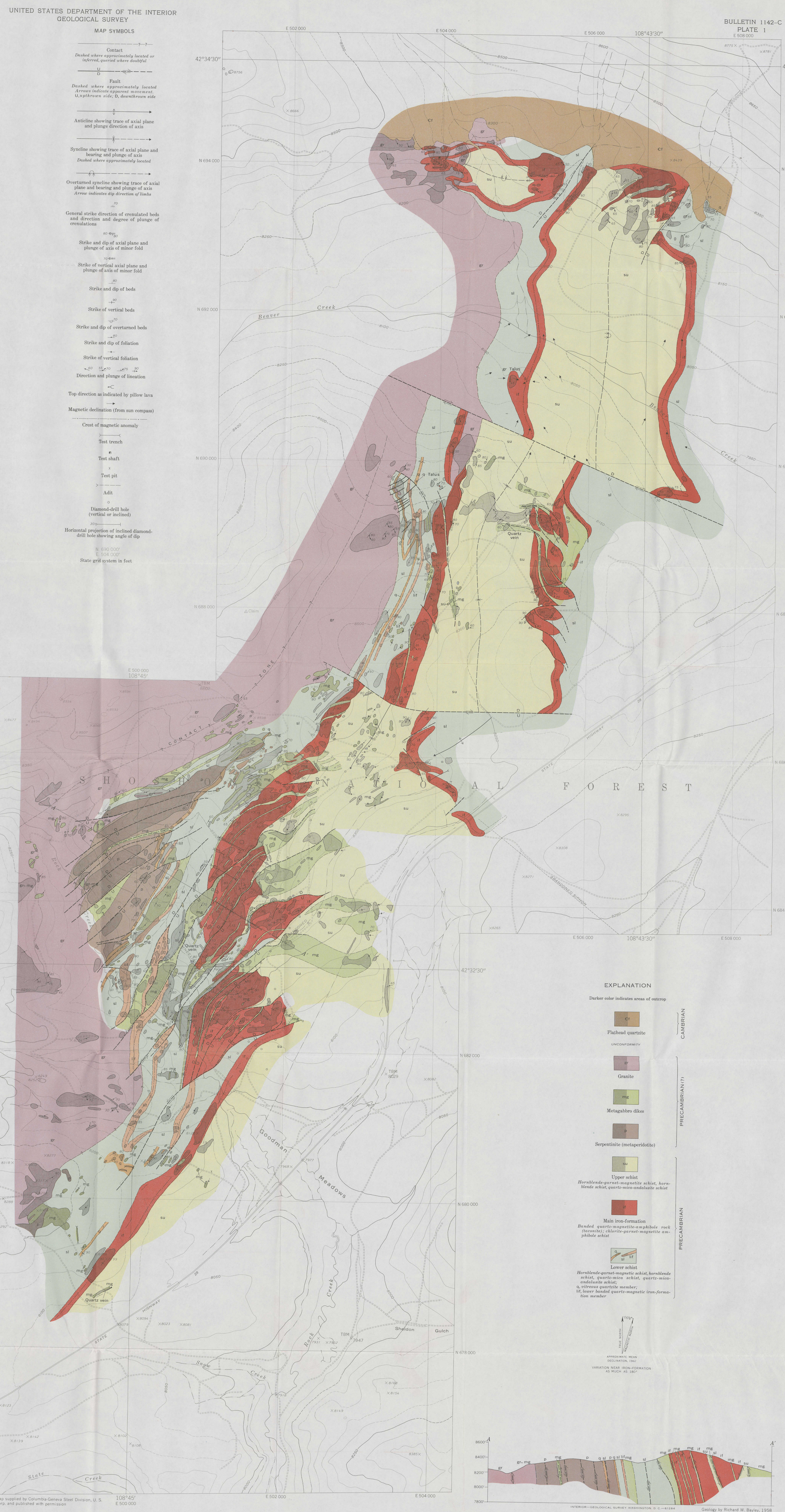

GEOLOGIC MAP AND SECTION OF IRON DEPOSITS NEAR ATLANTIC CITY, FREMONT COUNTY, WYOMING 



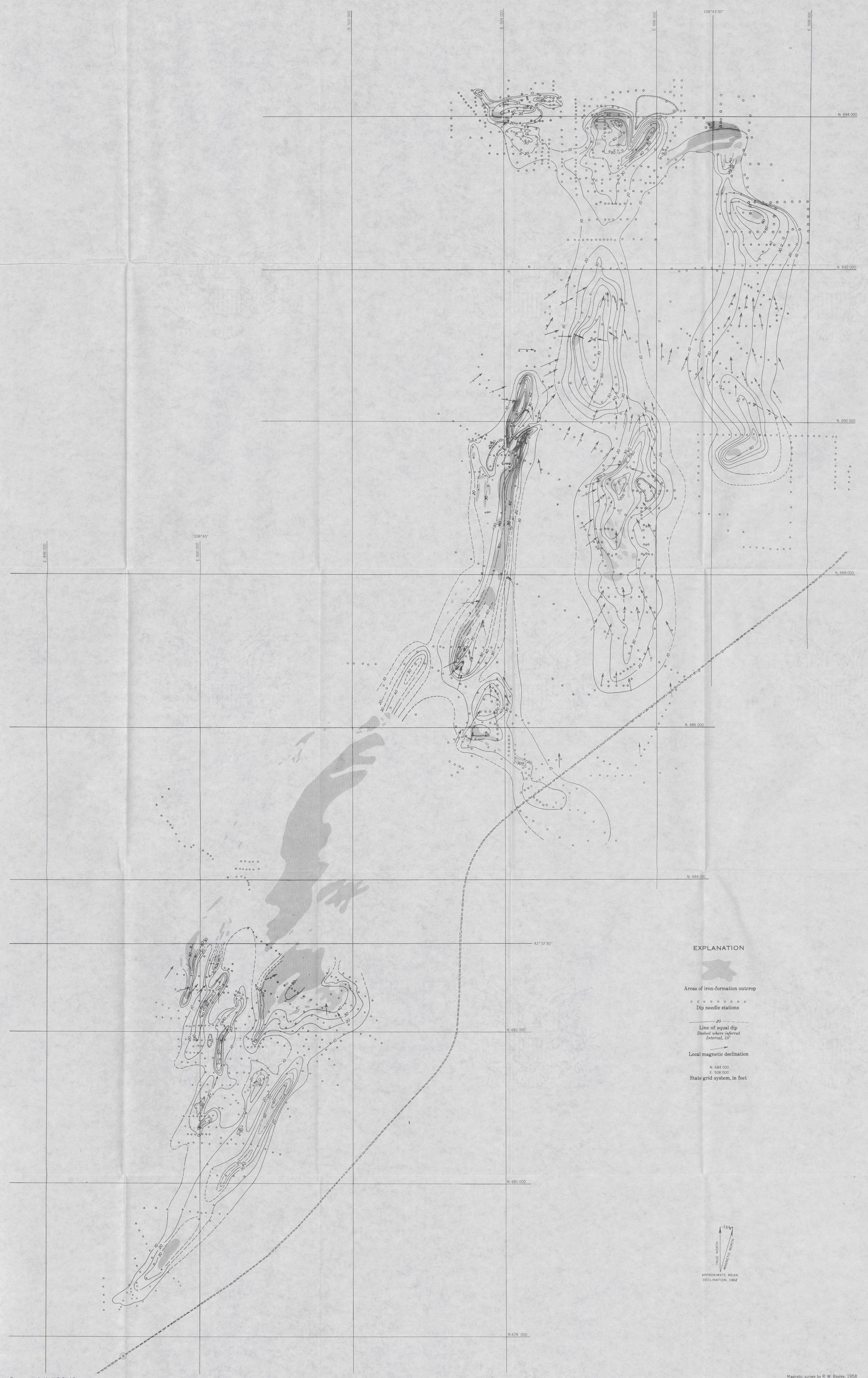


